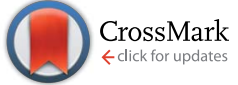

Cite this: RSC Adv., 2017, 7, 16041
Received 13th December 2016 Accepted 7th March 2017

DOI: 10.1039/c6ra28128a

rsc.li/rsc-advances

\section{An alternating polymer with fluorinated quinoxaline and 2,7-carbazole segments for photovoltaic devices $\uparrow$}

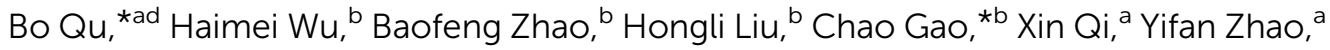 \\ Liyang Xuan ${ }^{\mathrm{a}}$ and Wei Weic
}

A novel alternating polymer, poly\{[N-9'-heptadecyl-2,7-carbazole $]$-alt-5,5-[5', $8^{\prime}$-di-2-thienyl-(6'-fluoro2', $3^{\prime}$-bis-(3'-octyloxyphenyl)-quinoxaline)]\} (PCzFTQx), based on mono-fluorinated quinoxaline derivative and 2,7-carbazole was synthesized and applied as electron donor material in polymer solar cells. Compared to the corresponding counterpart polymer without fluorine substituent (PCzTQx), PCzFTQx possesses similar absorption properties and optical bandgap ( $2.0 \mathrm{eV}$ ). However, the highest occupied molecular orbital (HOMO) energy level of PCzFTQx was lowered to $-5.31 \mathrm{eV}$, about $0.09 \mathrm{eV}$ deeper than that of PCzTQx. Benefit from the low-lying HOMO energy level caused by the strong electron deficient fluorine atom on the quinoxaline unit, the optimized photovoltaic device based on PCzFTQx and phenyl- $\mathrm{C}_{71}$-butyric acid methyl ester $\left(\mathrm{PC}_{71} \mathrm{BM}\right)$ exhibited an enhanced power conversion efficiency (PCE) of $5.19 \%$ with corresponding high open-circuit voltage $\left(V_{\text {oc }}\right)$ of $0.94 \mathrm{~V}$, relatively to those of $4.72 \%$ and $0.82 \vee$ for PCzTQx-based device. The experimental data indicated that fluorinated quinoxaline based polymer PCzFTQx should be a promising donor for polymer solar cells.

\section{Introduction}

Currently, polymer solar cells (PSCs) with bulk-heterojunction (BHJ) composite layers have attracted broad attention due to their potential applications for large area, low cost, and flexible renewable power sources. ${ }^{1-4}$ Although the power conversion efficiency (PCE) of PSCs was already promoted to $\sim 10 \%,{ }^{5-8}$ compared with silicon solar cells or other thin-film counterparts, high PCE for PSCs was pursued for its commercialization..$^{9-11}$ One key factor to obtain desired photovoltaic properties of PSCs is the development of promising donor conjugated polymers with a broad absorption range and a low-lying highest occupied molecular orbital (HOMO). Furthermore, an interpenetrating network with nano-scale phase separation and a large interfacial area in the donor/acceptor composite layer are also important factors to realize high efficiency of PSCs. ${ }^{\mathbf{1 2 , 1 3}}$ In order to improve open-circuit voltage $\left(V_{\mathrm{oc}}\right)$ and PCE of PSCs,

${ }^{a}$ State Key Laboratory for Artificial Microstructures and Mesoscopic Physics, Department of Physics, Peking University, Beijing, 100871, People's Republic of China.E-mail: bqu@pku.edu.cn; Tel: +86-10-62766902

${ }^{b} X i$ 'an Modern Chemistry Research Institute, Xi'an, Shaanxi, 710065, People's Republic of China.E-mail: chaogao74@gmail.com

'Institute of Advanced Materials, Nanjing University of Posts and Telecommunications, Nanjing, 210003, People's Republic of China

${ }^{d}$ New Display Device and System Integration Collaborative Innovation Center of the West Coast of the Taiwan Strait, Fuzhou, 350002, People's Republic of China

$\dagger$ Electronic supplementary information (ESI) available. See DOI: 10.1039/c6ra28128a an effective approach is to introduce a strong electron withdrawing group into donor polymer structure and accordingly achieved deep HOMO energy levels. ${ }^{14,15}$ For example, ketone, sulfonyl and fluorine atoms, with the characteristics of high electron affinity and none deleterious steric effect, were introduced into conjugated polymers and photovoltaic performance of the solar cells had been optimized. ${ }^{2,16-20}$ Moreover, the HOMO and lowest unoccupied molecular orbital (LUMO) energy levels could be lowered by incorporating fluorine atom into copolymers and high $V_{\text {oc }}$ of PSCs could be obtained..$^{21,22}$

Quinoxaline is a common-used electron-withdrawing moiety and the HOMO and band gaps of the quinoxaline-based alternating polymers could be effectively modulated due to the tunable structure of quinoxaline unit. ${ }^{23-25}$ Therefore, fluorinated quinoxaline-based alternating polymers showed low-lying HOMO and improved photovoltaic performance. ${ }^{\mathbf{2 6 - 3 1}}$ Herein, a new alternating polymer poly\{[N-9'-heptadecyl-2,7-carbazole]alt-5,5-[5', $8^{\prime}$-di-2-thienyl-(6'-fluoro-2', $3^{\prime}$-bis-(3' -octyloxyphenyl)quinoxaline)]\} (PCzFTQx) based on mono-fluorinated quinoxaline and 2,7-carbazole derivative was synthesized. Benefit from its lowered HOMO energy level $(-5.31 \mathrm{eV})$, about $0.09 \mathrm{eV}$ deeper than that of the non-fluorinated counterpart ${ }^{32}$ (named as PCzTQx in this work), a remarkable $V_{\text {oc }}(0.94$ V) and PCE (5.19\%) were obtained for PCzFTQx : phenyl-C $\mathrm{C}_{71}$-butyric acid methyl ester $\left(\mathrm{PC}_{71} \mathrm{BM}\right)$-based PSCs, which were $10 \%$ and $12 \%$ larger than those of the analogue PCzTQx-based devices under the same condition. The experimental data implied that PCzFTQx would be a promising donor copolymer for PSCs in future. 


\section{Experimental}

\subsection{Materials and characterization}

All chemicals and solvents were purchased from Aldrich or Alfa \& Aesar. Tetrahydrofuran (THF) is dried over $\mathrm{Na}$ /benzophenone ketyl and freshly distilled prior to use. 5,8-Bis((5bromothiophen-2-yl)-2,3-bis(3-octyloxy)phenyl)quinoxaline (M1) and 5,8-bis((5-bromothiophen-2-yl)-6-fluoro-2,3-bis(3-octyloxy) phenyl)quinoxaline (M2) that followed our previous work ${ }^{27}$ were prepared. 2,7-Bis $\left(4^{\prime}, 4^{\prime}, 5^{\prime}, 5^{\prime}\right.$-tetramethyl-1', $3^{\prime}, 2^{\prime}$-dioxaborolan-2'-yl)- $N-9^{\prime \prime}$-heptadecanylcarbazole (M3) ${ }^{33}$ were synthesized according to the reported literatures. The synthetic routes of monomers and copolymers are given in Scheme 1.

\subsection{Synthesis of PCzFTQx and PCzTQx}

In a $50 \mathrm{~mL}$ dry flask, monomer M1 $(175.7 \mathrm{mg}, 0.2 \mathrm{mmol})$ or M2 (172.2 mg, $0.2 \mathrm{mmol})$ and 2,7-bis $\left(4^{\prime}, 4^{\prime}, 5^{\prime}, 5^{\prime}\right.$-tetramethyl-1' ${ }^{\prime}, 3^{\prime}, 2^{\prime}$ dioxaborolan-2'-yl)- $N-9^{\prime \prime}$-heptadecanyl-carbazole M3 $(131.5 \mathrm{mg}$, $0.2 \mathrm{mmol}$ ) were dissolved in a mixture of $20 \%$ aqueous tetraethylammonium hydroxide $(1.5 \mathrm{~mL})$ and degassed toluene (10 $\mathrm{mL})$. The mixture was flushed with nitrogen for $30 \mathrm{~min}$. Tris(dibenzylideneacetone)dipalladium $(0)\left(\mathrm{Pd}_{2}(\mathrm{dba})_{3}\right)(3.7 \mathrm{mg})$ and tri(o-tolyl)phosphine $\left(\mathrm{P}(o \text {-Tol })_{3}\right) 6.5 \mathrm{mg}$ were added, flushed with nitrogen again. Then the mixture was vigorously stirred at $100{ }^{\circ} \mathrm{C}$ for $48 \mathrm{~h}$ under a nitrogen atmosphere. The polymer was end-capped by adding phenyl boronic acid $(2.4 \mathrm{mg})$ and bromobenzene $(2.2 \mu \mathrm{L})$ at the end of polymerization. After cooling to room temperature, the solution was poured into methanol. The obtained polymer was then subjected to Soxhlet-extracted with methanol, hexane and chloroform successively. The chloroform solution was concentrated to a small volume, and precipitated by pouring this solution into methanol. Finally, the polymer was collected by filtration, dried under vacuum at $50{ }^{\circ} \mathrm{C}$ overnight.

For PCzTQx. (148 mg, yield 67.1\%). ${ }^{1} \mathrm{H}$ NMR $\left(\mathrm{CDCl}_{3}, 500\right.$ $\mathrm{MHz}) \delta$ (ppm): 8.22 (br, 2H), 7.98 (br, 2H), 7.71 (br, 6H), 7.48 (br, $4 \mathrm{H}), 7.36$ (br, 4H), 7.01 (d, 2H, $J=10 \mathrm{~Hz}$ ), 3.95-3.86 (br, 5H). Gel permeation chromatography (GPC, as shown in Fig. S1 in the $\mathrm{ESI} \dagger$ ) (tetrahydrofuran, polystyrene standard): $M_{\mathrm{n}}=9.93 \mathrm{kDa}$, $M_{\mathrm{w}}=17.89 \mathrm{kDa}, \mathrm{PDI}=1.80$. Anal. calcd for $\left(\mathrm{C}_{73} \mathrm{H}_{89} \mathrm{~N}_{3} \mathrm{O}_{2} \mathrm{~S}_{2}\right)_{n}$ (\%): C 79.37, H 8.12, N 3.80. Found (\%): C 77.77, H 7.86, N 3.77.

For PCzFTQx. (155 mg, 69.2\% yield). ${ }^{1} \mathrm{H}$ NMR $\left(\mathrm{CDCl}_{3}, 500\right.$ $\mathrm{MHz}) \delta(\mathrm{ppm}): 8.22$ (br, 1H), 7.96 (br, 2H), 7.72 (br, 6H), 7.48 (br, $4 \mathrm{H}), 7.36$ (br, $4 \mathrm{H}), 7.00$ (d, 2H, $J=8 \mathrm{~Hz}), 3.95-3.86$ (br, 5H). GPC (tetrahydrofuran, polystyrene standard): $M_{\mathrm{n}}=54.37 \mathrm{kDa}, M_{\mathrm{w}}=$ $127.79 \mathrm{kDa}, \mathrm{PDI}=2.35$. Anal. calcd for $\left(\mathrm{C}_{73} \mathrm{H}_{88} \mathrm{~N}_{3} \mathrm{O}_{2} \mathrm{FS}_{2}\right)_{n}(\%): \mathrm{C}$ 78.10, H 7.90, N 3.74. Found (\%): C 77.99, H 7.80, N 3.53.

\subsection{Characterization}

All the compounds were characterized by nuclear magnetic resonance spectra (NMR) recorded (Bruker AV 500 spectrometer) in chloroform- $d\left(\mathrm{CDCl}_{3}\right)$ at room temperature using tetramethylsilane (TMS) as an internal reference. The chemical shifts were accounted in ppm related to the singlet of $\mathrm{CDCl}_{3}$ at $7.26 \mathrm{ppm}$ for ${ }^{1} \mathrm{H}$ NMR. Molecular weights and distributions of the copolymers were estimated by gel permeation chromatography (GPC) method, tetrahydrofuran (THF) as eluent and polystyrene as standard. The absorption spectra and thermogravimetric analysis (TGA, as shown in Fig. S2 in the ESI $\dagger$ ) were measured with a Unico UV-2102 scanning spectrophotometer and a Universal V2.6D TA instrument, respectively. The electrochemical cyclic voltammetry $(\mathrm{CV})$ was determined by a $\mathrm{CHI}$ 660D Electrochemical Workstation with glassy carbon, Pt wire, and $\mathrm{Ag} / \mathrm{Ag}^{+}$electrodes as the working electrode, counter electrode, and reference electrode respectively in a $0.1 \mathrm{~mol} \mathrm{~L}^{-1}$ tetrabutylammonium hexafluorophosphate $\left(\mathrm{Bu}_{4} \mathrm{NPF}_{6}\right)$ acetonitrile solution. Polymers in chloroform solution (analytical reagent, $2 \mathrm{mg} \mathrm{mL} \mathrm{mL}^{-1}$ ) were drop casted onto working electrode and dried in air at room temperature. Atomic force microscopy (AFM) measurement of the surface morphology of samples was conducted in air under ambient condition using the PicoPlus microscope (Agilent).

\subsection{PSCs fabrication and characterization}

PSCs with the configuration of ITO/PEDOT : PSS/ PCzFTQx : PC $_{71} \mathrm{BM} /$ poly[(9,9-bis(3'-( $N, N$-dimethylamino)propyl)2,7-fluorene)-alt-2,7-(9,9-dioctylfluorene)] (PFN)/Al were fabricated and characterized in this work. With varying the weight ratio of PCzFTQx : $\mathrm{PC}_{71} \mathrm{BM}$ from $1: 1$ to $1: 4$, the photovoltaic properties of PSCs were systematically investigated. For comparison, the control device based on PCzTQx : $\mathrm{PC}_{71} \mathrm{BM}$ $(1: 3)$ (the optimal specimen in the previous literature ${ }^{32}$ ) was also prepared with the same configuration and experimental condition in this work.

ITO-coated glass with sheet resistance of $\sim 15 \Omega$ per square $\left(\Omega \square^{-1}\right.$ ) was used as the anode. The ITO glass was ultrasonically cleaned with detergent, distilled water, acetone, isopropyl alcohol, and then treated with ultraviolet-ozone (Ming Heng, PDC-MG) for $20 \mathrm{~min}$. Then a $40 \mathrm{~nm}$ thick PEDOT : PSS (Clevios P VP AI 4083, H. C. Starck Inc.) layer was spin-coated from an aqueous solution onto ITO substrates, followed by being annealed at $120{ }^{\circ} \mathrm{C}$ for $30 \mathrm{~min}$ on a hotplate in air. The substrates were transferred into a nitrogen-filled glove box. Then the photoactive layers were prepared by spin-coating
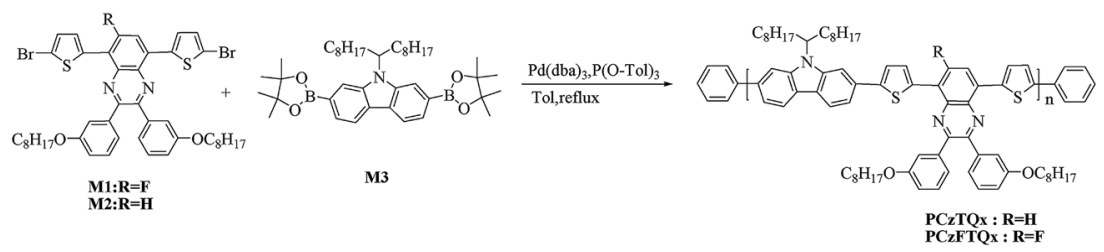

Scheme 1 Synthetic route of PCzFTQx and PCzTQx 


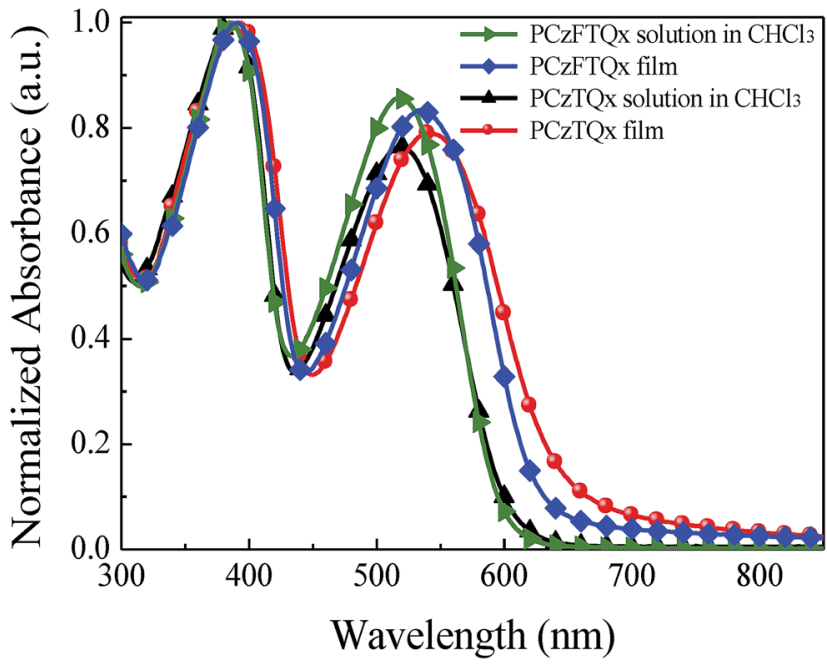

Fig. 1 Absorption spectra of PCzFTQx and PCzTQx.

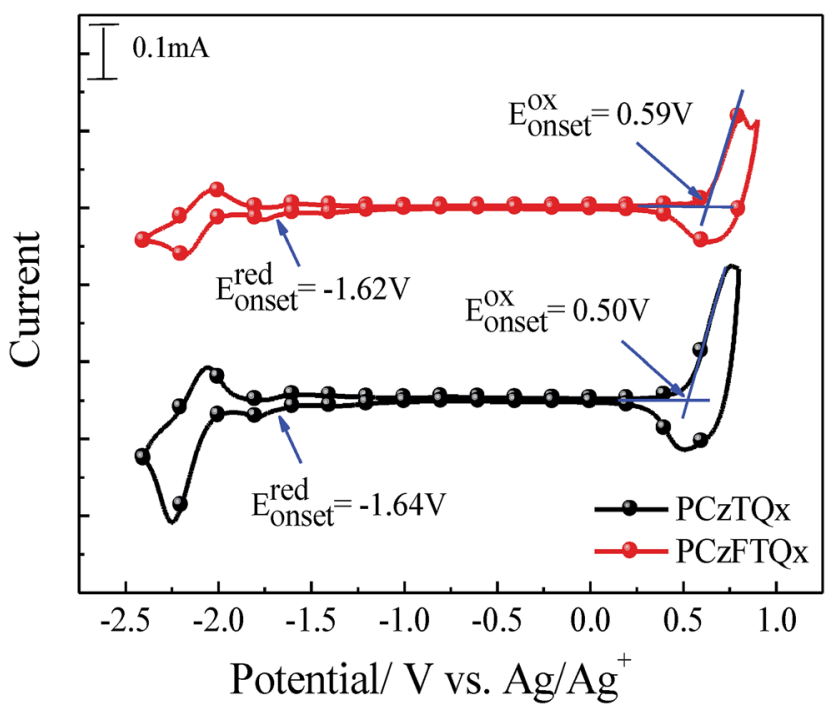

Fig. 2 Cyclic voltammogram of PCzFTQx and PCzTQx films on glassy carbon electrode $\left(0.1 \mathrm{~mol} \mathrm{~L}{ }^{-1} \mathrm{Bu}_{4} \mathrm{NPF}_{6}\right.$, acetonitrile solution with a scan rate of $100 \mathrm{mV} \mathrm{s}^{-1}$ ).

(1000 rpm, $30 \mathrm{~s}$ ) a blend solution of the polymer and $\mathrm{PC}_{71} \mathrm{BM}$ in ortho-dichlorobenzene (oDCB) on the top of ITO/PEDOT : PSS substrates. The thickness of the photoactive layers was controlled in the range of $80-100 \mathrm{~nm}$. A $5 \mathrm{~nm}$ PFN layer was then spin-coated from methanol solution in the presence of a trace amount of acetic acid onto the active layer. The thin PFN layer was employed as the cathode interlayer since it could improve the electron extraction. ${ }^{6}$ Finally, the substrates were

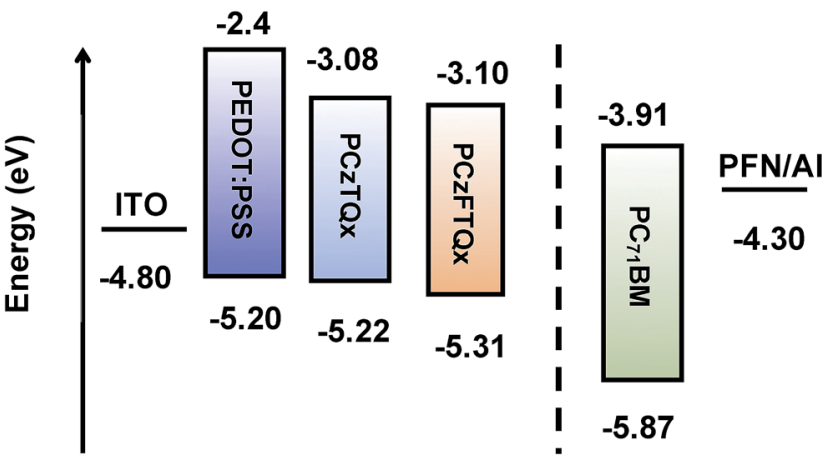

Fig. 3 Schematic illustration of relative positions of HOMO/LUMO energy levels of the materials in the PSCs.

transferred into a vacuum chamber and $\mathrm{Al}$ cathodes $(\sim 120 \mathrm{~nm})$ were thermally deposited onto the substrates. The effective area of PSCs was $\sim 0.16 \mathrm{~cm}^{2}$ controlled by the shadow mask. The photovoltaic properties of PSCs were recorded by $J-V$ measurement (using a Keithley 2400 source meter) under 1 sun, AM 1.5G spectrum from a solar simulator (Newport model 94021A, 100 $\mathrm{mW} \mathrm{cm}^{-2}$ ). A monocrystal silicon cell (VLSI Standards Inc.) calibrated by the National Renewable Energy Laboratory (NREL) is used as a reference. The incident photo to current conversion efficiency spectra were measured by using a Hypermonolight System (QTEST 1000 AD, Crowntech Inc.).

\section{Results and discussion}

\subsection{Thermal properties}

As shown in the TGA curves of the polymers (Fig. S2 in the ESI $\dagger$ ), the thermal decomposition temperature ( $5 \%$ weight loss) of PCzFTQx was about $403{ }^{\circ} \mathrm{C}$, slightly lower than that of PCzTQx $\left(405{ }^{\circ} \mathrm{C}\right)$, indicating its good thermal stability for photovoltaic applications.

\subsection{Absorption properties}

The normalized UV-vis absorption spectra of PCzFTQx and PCzTQx in chloroform $\left(\mathrm{CHCl}_{3}\right)$ solution and film states were exhibited in Fig. 1. The absorption peaks of PCzFTQx and PCzTQx in $\mathrm{CHCl}_{3}$ solution were almost identical. The peaks located at $386 \mathrm{~nm}$ and $517 \mathrm{~nm}$, which were attributed to the absorption of carbazole segment and intramolecular charge transfer, respectively. ${ }^{32}$ As to the film state, the absorption peaks of PCzFTQx and PCzTQx in the long wavelength region were red shifted to $536 \mathrm{~nm}$ and $542 \mathrm{~nm}$, respectively. The weak bathochromic shift effect of the polymers from solution state to film state implied that the aggregation and chain-chain stacking of PCzFTQx and PCzTQx were relatively limited. The optical band gap $\left(E_{\mathrm{g}}^{\mathrm{opt}}\right)$ of the polymers

Table 1 Electrochemical potentials and energy levels of PCzFTQx and PCzTQx

\begin{tabular}{lllllll}
\hline Polymers & $E_{\text {onset }}^{\text {ox }}(\mathrm{V})$ & $E_{\text {onset }}^{\text {red }}(\mathrm{V})$ & $E_{\text {HOMO }}(\mathrm{eV})$ & $E_{\text {LUMO }}(\mathrm{eV})$ & $E_{\mathrm{g}}^{\mathrm{ec}}(\mathrm{eV})$ & $E_{\mathrm{g}}^{\text {opt }}(\mathrm{eV})$ \\
\hline PCzFTQx & 0.59 & -1.62 & -5.31 & -3.10 & 2.21 \\
PCzTQx & 0.50 & -1.64 & -5.22 & -3.08 & 2.04 & 2.14
\end{tabular}


was calculated to be $2.04 \mathrm{eV}$ for PCzFTQx and $1.98 \mathrm{eV}$ for PCzTQx from the absorption onset of the films.

\subsection{Electrochemical properties}

In order to study the electrochemical properties of the polymers, cyclic voltammetry (CV) was carried out using an electrochemical workstation. CV curves of PCzFTQx and PCzTQx films were measured as shown in Fig. 2. The level of ferrocene/ferrocenium $\left(\mathrm{Fc} / \mathrm{Fc}^{+}\right)$was $-4.72 \mathrm{eV}$ below the vacuum level. ${ }^{29}$ The former potential of $\mathrm{Fc} / \mathrm{Fc}^{+}$was $\sim 0.08 \mathrm{eV}$ against $\mathrm{Ag} /$ $\mathrm{Ag}^{+}$. The onset oxidation and reduction potential of PCzFTQx film located at $0.59 \mathrm{~V}$ and $-1.62 \mathrm{~V}$, respectively. Therefore, the

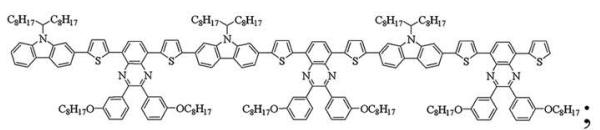

PCzTQx

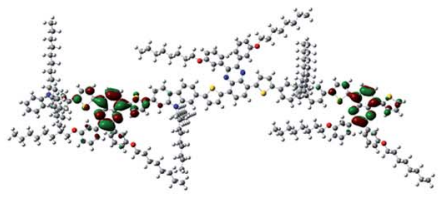

$\mathrm{LUMO}+1=-2.13 \mathrm{eV}$

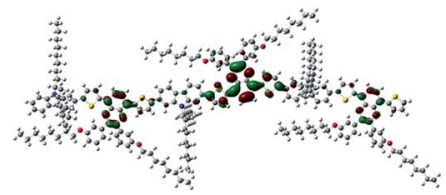

$\mathrm{LUMO}=-2.23 \mathrm{eV}$

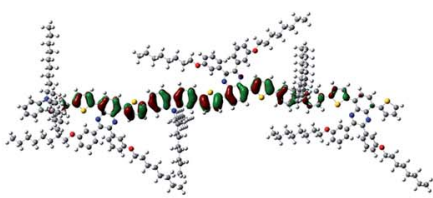

$\mathrm{HOMO}=-4.59 \mathrm{eV}$

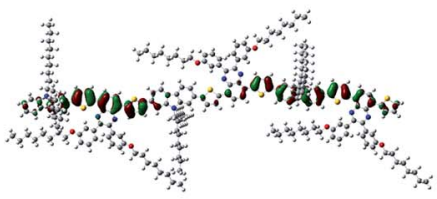

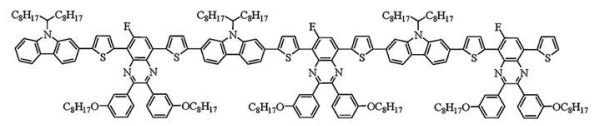

PCzFTQx

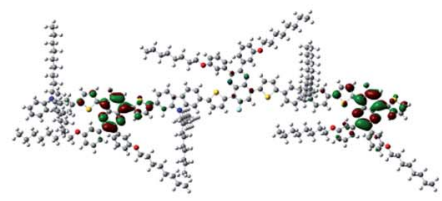

$\mathrm{LUMO}+1=-2.19 \mathrm{eV}$

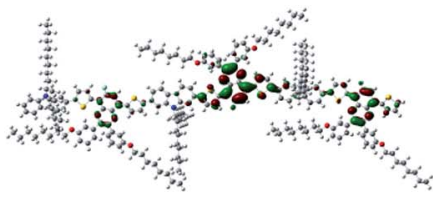

$\mathrm{LUMO}=-2.26 \mathrm{eV}$

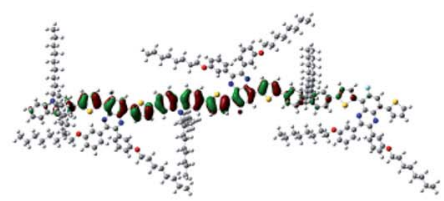

$\mathrm{HOMO}=-4.64 \mathrm{eV}$

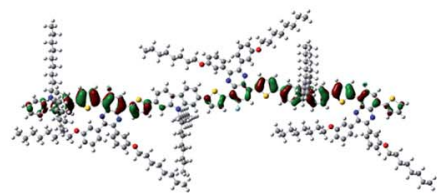

HOMO- $1=-4.78 \mathrm{eV}$

HOMO- $1=-4.74 \mathrm{eV}$

Fig. 4 Molecular structures and electron density of LUMO+1, LUMO, HOMO and HOMO-1 for PCzTQx and PCzFTQx computed at the B3LYP/ 6-31G* level. 
HOMO and LUMO of PCzFTQx were evaluated to be $-5.31 \mathrm{eV}$ and $-3.10 \mathrm{eV}$, respectively. The electrochemical energy band gap $\left(E_{\mathrm{g}}^{\mathrm{ec}}\right)$ of PCzFTQx film was calculated to be $2.21 \mathrm{eV}$. Although $E_{\mathrm{g}}^{\mathrm{ec}}$ value was a little bit larger than $E_{\mathrm{g}}^{\mathrm{opt}}(2.04 \mathrm{eV})$ estimated from the UV-vis spectra, it was still in the range of error (0.1-0.5 eV). As to PCzTQx film, the HOMO and LUMO were measured to be $-5.22 \mathrm{eV}$ and $-3.08 \mathrm{eV}$, respectively. The $E_{\mathrm{g}}^{\mathrm{ec}}$ and $E_{\mathrm{g}}^{\mathrm{opt}}$ of PCzTQx were $2.14 \mathrm{eV}$ and $1.98 \mathrm{eV}$, slightly smaller than those of PCzFTQx. The energy level data were summarized in Table 1 and the schematic illustration of energy levels of PCzFTQx, PCzTQx, $\mathrm{PC}_{71} \mathrm{BM}^{34}$ and PEDOT : PSS $^{35}$ was depicted in Fig. 3. The HOMO of PCzFTQx was $\sim 0.09 \mathrm{eV}$ deeper than that of PCzTQx, which was ascribed to the introduction of fluorine atom onto the quinoxaline segment in PCzFTQx. ${ }^{27,29}$ Therefore, the gap between the HOMO level of PCzFTQx and LUMO level of $\mathrm{PC}_{71} \mathrm{BM}$ was as large as $1.40 \mathrm{eV}$, which facilitated high $V_{\mathrm{oc}}$ of photovoltaic devices. Moreover, the LUMO level of PCzFTQx was $\sim 0.81 \mathrm{eV}$ higher than that of $\mathrm{PC}_{71} \mathrm{BM}$, then electrons could transfer automatically at the donor/acceptor interface.

\subsection{Theoretical calculations}

Quantum chemistry calculation by the DFT (B3LYP/6-31G* level) method was employed to demonstrate the electronic structures of the PCzTQx and PCzFTQx. Three repeat units were chosen as the model compounds for the simulations of PCzTQx and PCzFTQx, and the actual long alkyl groups were kept without simplification. As shown in Fig. 4, the electron density in HOMO orbitals distributed along the whole backbone despite somewhat more intensely at carbazole conjugated units and less at quinoxaline units. However, the electron density in LUMO orbitals mainly localized at the quinoxaline units. The HOMO-1 electron density distributed more intensely in $\pi$ bridge thiophene and carbazole conjugated units, while the LUMO+1 electron density distributed more intensely at the quinoxaline units. The electron density distribution of the different orbitals implied that the internal charge transfers were possible in the conjugated systems. It should be noted that the $\mathrm{F}$ atom that incorporated onto the quinoxaline unit showed significant effect on the HOMO and LUMO energy levels of PCzFTQx $(-4.64 \mathrm{eV} /-2.26 \mathrm{eV})$. The additional $\mathrm{F}$ atoms depressed both HOMO and LUMO energy levels, which agreed well with the trend of electrochemical results.

\subsection{Photovoltaic properties}

In order to study the photovoltaic properties of PCzFTQx, PSCs with the conventional structure of ITO/PEDOT:PSS/ PCzFTQx : PC $_{71} \mathrm{BM} / \mathrm{PFN} / \mathrm{Al}$ were fabricated. PCzFTQx was used as the electron donor and $\mathrm{PC}_{71} \mathrm{BM}$ as the electron acceptor. Chlorobenzene was used as the solvent to prepare the PCzFTQx : $\mathrm{PC}_{71} \mathrm{BM}$ blend films. The weight ratio of PCzFTQx : $\mathrm{PC}_{71} \mathrm{BM}$ was changed from $1: 1$ to $1: 4$ and $J-V$ curves of PSCs were modulated accordingly as shown in Fig. 5 . When the weight ratio of PCzFTQx : $\mathrm{PC}_{71} \mathrm{BM}$ reached $1: 3$, the PSC exhibited a reasonable photovoltaic performance as shown in Table 2 and the $V_{\mathrm{oc}}, J_{\mathrm{sc}}, \mathrm{FF}$ and PCE values were evaluated to be $0.94 \mathrm{~V}, 9.71 \mathrm{~mA} \mathrm{~cm} \mathrm{~cm}^{-2}, 0.56$ and $5.09 \%$, respectively. As

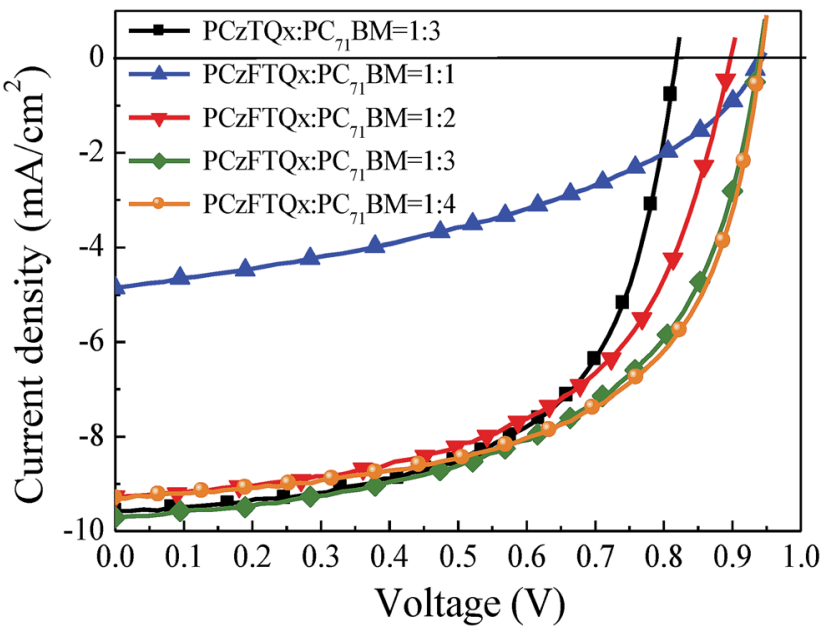

Fig. 5 Current density vs. voltage characteristics of PSCs under AM $1.5 \mathrm{G}$ irradiation of $100 \mathrm{~mW} \mathrm{~cm}^{-2}$.

Table 2 Photovoltaic data of the polymer solar cells

\begin{tabular}{lllll}
\hline PCzFTQx : PC $_{71} \mathrm{BM}^{a}$ & $V_{\text {oc }}(\mathrm{V})$ & $J_{\text {sc }}\left(\mathrm{mA} \mathrm{cm}^{-2}\right)$ & FF & PCE (\%) \\
\hline $1: 1$ & 0.94 & 4.86 & 0.42 & 1.92 \\
$1: 2$ & 0.90 & 9.27 & 0.57 & 4.70 \\
$1: 3$ & 0.94 & 9.71 & 0.56 & 4.09 \\
$1: 4$ & 0.94 & 9.31 & 0.59 & 5.19 \\
PCzTQx $: \mathrm{PC}_{71} \mathrm{BM}(1: 3)^{a}$ & 0.82 & 9.57 & 0.60 & 4.72
\end{tabular}

${ }^{a}$ The thickness of the active layer was in the range of $80-100 \mathrm{~nm}$.

expected, the PSC based on PCzFTQx : $\mathrm{PC}_{71} \mathrm{BM}(1: 3)$ has higher $V_{\mathrm{oc}}$ and PCE than those of the corresponding PCzTQxbased device (blend ratio of $1: 3$ ), ${ }^{32}$ which was ascribed to the introduction of fluorine atom into the polymer and the lowlying HOMO level of PCzFTQx. It was worthy to note that the PSC with PCzFTQx : $\mathrm{PC}_{71} \mathrm{BM}(1: 3)$ as the active layer exhibited the highest $J_{\mathrm{sc}}$ of $9.71 \mathrm{~mA} \mathrm{~cm} \mathrm{~cm}^{-2}$ in this work, approximately 0.14 $\mathrm{mA} \mathrm{cm}{ }^{-2}$ higher than that of PCzTQx control device. Moreover, when the weight ratio of PCzFTQx : $\mathrm{PC}_{71} \mathrm{BM}$ reached $1: 4$, the highest PCE of 5.19\% was achieved, mainly due to the increased FF of 0.59. Therefore, the PCE value was almost unaltered when the ratio of PCzFTQx : $\mathrm{PC}_{71} \mathrm{BM}$ changed from $1: 3$ to $1: 4$.

The external quantum efficiency (EQE) curves were also recorded to characterize the photovoltaic properties of the PSCs as shown in Fig. 6. The EQE curves covered from $350 \mathrm{~nm}$ to $650 \mathrm{~nm}$, which matched well with the absorption range of the organic photoactive layers. Compared with any other PCzFTQx : PC $_{71} \mathrm{BM}$-based devices with different blend ratios, the PCzFTQx : $\mathrm{PC}_{71} \mathrm{BM}(1: 3)$-based device exhibited a high EQE value up to $62 \%$, leading to a high short circuit current density of $9.71 \mathrm{~mA} \mathrm{~cm}^{-2}$.

Atomic force microscopy (AFM) was conducted to evaluate the phase-separated morphologies of the blend films and the topography images $(5 \mu \mathrm{m} \times 5 \mu \mathrm{m})$ of PCzTQx : $\mathrm{PC}_{71} \mathrm{BM}(1: 3)$ and PCzFTQx : $\mathrm{PC}_{71} \mathrm{BM}(1: 4)$ corresponding to the best photovoltaic performance were shown in Fig. 7. The 


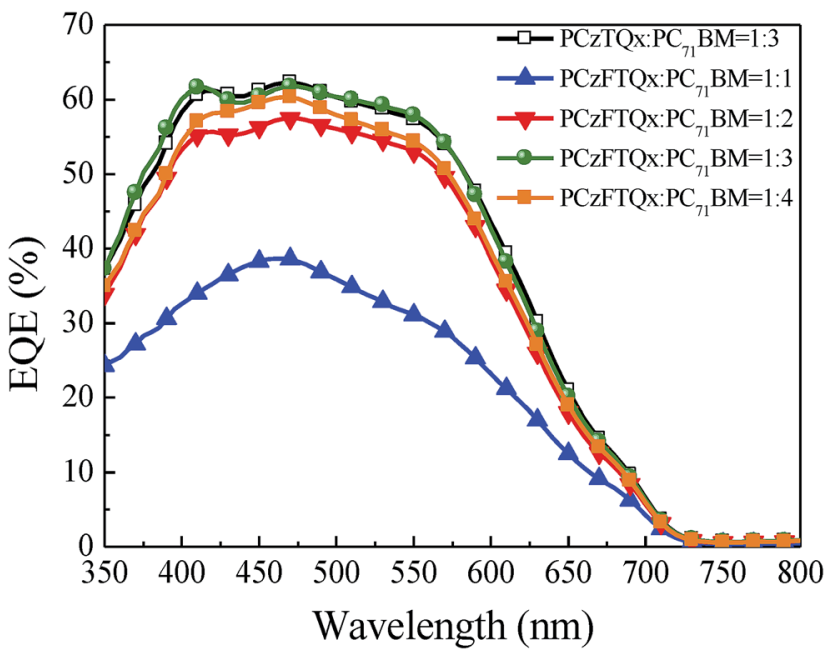

Fig. 6 EQE spectra of the PSCs.

interpenetrating feature with bicontinuous network between the polymer and $\mathrm{PC}_{71} \mathrm{BM}$ was realized for both the two blend films. PCzTQx : $\mathbf{P C}_{71} \mathrm{BM}$ blend film showed a relatively smooth surface with a root-mean-square roughness (RMS) of $2.99 \mathrm{~nm}$ and an ideal domain size of $10-20 \mathrm{~nm}$, which were favorable for efficient diffusion of excitons to donor-acceptor interfaces. ${ }^{36,37}$ However, for the fluorinated polymer PCzFTQx-based blend film, RMS value was enlarged $(5.27 \mathrm{~nm})$ with the corresponding domain size of 40-60 nm, which was somewhat larger than the typical exciton diffusion length of $c a .10 \mathrm{~nm},{ }^{13}$ thus was not desired for efficient exciton dissociation at the $\mathrm{D} / \mathrm{A}$ interfaces.

To get insight into the charge transporting property of the two polymers, the hole-only devices were fabricated to measure the hole mobility using the space-charge-limited current (SCLC) method. The hole-only devices employed the structure of ITO/ PEDOT : PSS/polymer : $\mathrm{PC}_{71} \mathrm{BM} / \mathrm{MoO}_{3} / \mathrm{Al}$. And the $J-V$ characteristics of the hole-only devices were measured and fit the dark current using the SCLC model, which was described by the equation: $J=\frac{9}{8} \varepsilon_{0} \varepsilon \mu \frac{\left(V_{\mathrm{app}}-V_{\mathrm{s}}-V_{\mathrm{bi}}\right)^{2}}{L^{3}}$, where $J$ was the current density, $\varepsilon_{0}$ was the permittivity of free space, $\varepsilon$ was the relative

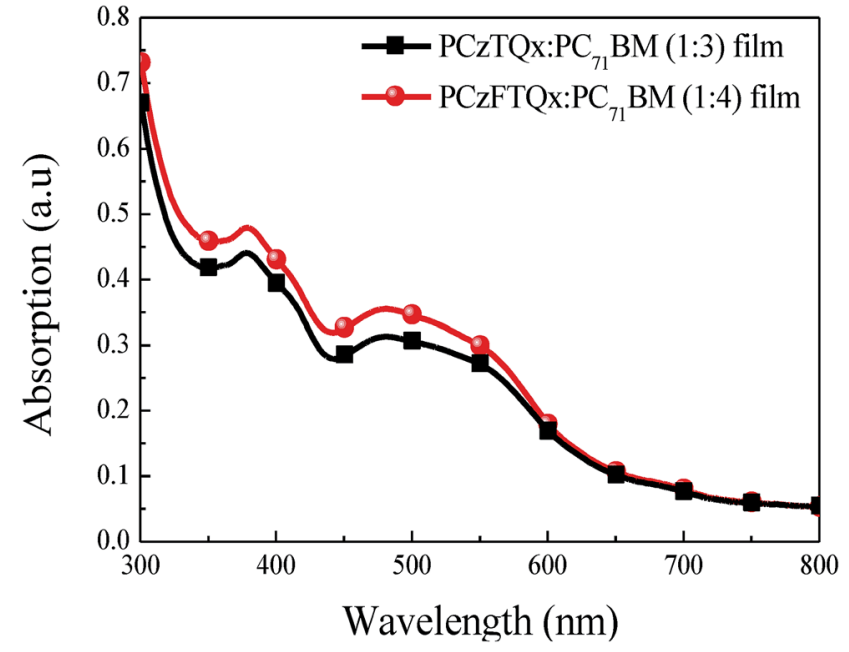

Fig. 8 Absorption spectra of PCzTQx: $\mathrm{PC}_{71} \mathrm{BM} \quad(1: 3)$ and PCzFTQx : $\mathrm{PC}_{71} \mathrm{BM}(1: 4)$ films.

permittivity of polymers, $\mu$ was the charge carrier mobility, $V_{\text {app }}$ was the applied voltage, $V_{\mathrm{s}}$ was the voltage drop from the substrate's series resistance and $V_{\mathrm{bi}}$ was the built-in voltage. As illustrated in Fig. S3, $\uparrow$ the hole $\left(\mu_{\mathrm{h}}\right)$ mobilities were calculated through the slope of the $J^{1 / 2}-V$ curves, which were exhibited in Table S1. $\dagger$ Relative to the $\mu_{\mathrm{h}}$ value of $3.12 \times 10^{-5} \mathrm{~cm}^{2} \mathrm{~V}^{-1} \mathrm{~s}^{-1}$ for PCzTQx, the fluorinated polymer PCzFTQx showed slightly high $\mu_{\mathrm{h}}$ value of $6.18 \times 10^{-5} \mathrm{~cm}^{2} \mathrm{~V}^{-1} \mathrm{~s}^{-1}$, which was consistent with the experimental data of the previous literature. ${ }^{22}$ And the high $\mu_{\mathrm{h}}$ of PCzFTQx was beneficial to the photovoltaic performance of the corresponding devices.

The absorption spectra of PCzTQx : $\mathrm{PC}_{71} \mathrm{BM}$ and PCzFTQx : $\mathrm{PC}_{71} \mathrm{BM}$ active layers under the optimal weight ratios were recorded in Fig. 8. It can be seen that in the region from $300 \mathrm{~nm}$ to $440 \mathrm{~nm}$, the PCzFTQx blend film showed slightly high absorption property, which was mainly resulted from the high ratio of $\mathrm{PC}_{71} \mathrm{BM}$ in the blend film. In addition, a little stronger absorption for PCzFTQx blend film in the range of 440-600 $\mathrm{nm}$ might be ascribed to the slightly enhanced absorption behavior of PCzFTQx pristine film in this region as
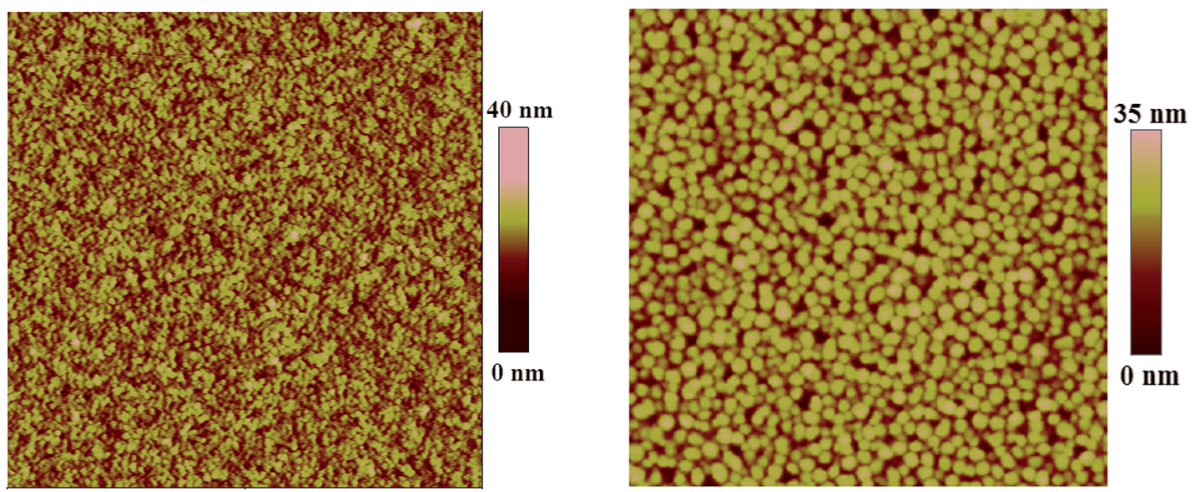

Fig. 7 AFM topography images $(5 \mu \mathrm{m} \times 5 \mu \mathrm{m}$ ) of ITO/PEDOT : PSS/PCzTQx : PC 71 BM (1: 3) (left, RMS = $2.99 \mathrm{~nm}$ ), and ITO/PEDOT : PSS/ PCzFTQx : $\mathrm{PC}_{71} \mathrm{BM}(1: 4)$ (right, $\mathrm{RMS}=5.27 \mathrm{~nm}$ ). 
seen in Fig. 1, which would be benefit to the improvement of photocurrent. As described ahead, the domain size of PCzFTQx : PC $_{71} \mathrm{BM}$ blend film was larger to some extent and not suitable for the efficient exciton dissociation. Then, the $J_{\mathrm{sc}}$ of the corresponding PCzFTQx : $\mathrm{PC}_{71} \mathrm{BM}$ based device was 9.31 $\mathrm{mA} \mathrm{cm}^{-2}$, almost equal to that of PCzTQx:PC ${ }_{71} \mathrm{BM}$ based device. Therefore, if further improvement of morphology can be adopted to obtain ideal domain size and phase separation, enhanced photovoltaic performance may be anticipated for PCzFTQx based solar cells.

\section{Conclusions}

A novel copolymer PCzFTQx with mono-fluorinated quinoxaline derivative and 2,7-carbazole segment was reported and the photovoltaic properties of PCzFTQx were investigated in this work. Due to the introduction of fluorine atom in quinoxaline unit, PCzFTQx exhibited a lowered HOMO level $(-5.31 \mathrm{eV})$, about $0.09 \mathrm{eV}$ deeper than that of the non-fluorinated counterpart PCzTQx $(-5.22 \mathrm{eV})$. High $V_{\text {oc }}(0.94 \mathrm{~V})$ and PCE $(5.19 \%)$ were achieved for the optimized PCzFTQx : PC $_{71} \mathrm{BM}$-based PSCs, which were $12 \%$ and $10 \%$ larger than those of the nonfluorinated analogue PCzTQx-based devices. Therefore, the fluorine atom in PCzFTQx was an effective electron-withdrawing unit and the accompanying beneficial modulation of the energy levels for PCzFTQx was realized accordingly. Hence, PCzFTQx showed remarkable photovoltaic properties and would be a promising donor candidate for PSCs and other optoelectronic devices.

\section{Acknowledgements}

This work was supported by the National Natural Science Foundation of China under grant No. 11574013 and 11527901, the National Fund for Fostering Talents of Basic Science (NFFTBS) with grant No. J1030310 and J1103205.

\section{Notes and references}

1 C. W. Tang, Appl. Phys. Lett., 1986, 48, 183-185.

2 J. Hou, H. Y. Chen, S. Zhang, R. I. Chen, Y. Yang, Y. Wu and G. Li, J. Am. Chem. Soc., 2009, 131, 15586.

3 B. Qu, Z. Jiang, Z. Chen, L. Xiao, D. Tian, C. Gao, W. Wei and Q. Gong, J. Appl. Polym. Sci., 2012, 124, 1186-1192.

4 H. X. Zhou, L. Q. Yang, S. C. Price, K. J. Knight and W. You, Angew. Chem., Int. Ed., 2010, 49, 7992-7995.

5 Y. H. Liu, J. B. Zhao, Z. K. Li, C. Mu, W. Ma and H. W. Hu, Nat. Commun., 2014, 5, 5293.

6 Z. C. He, B. Xiao, F. Liu, H. B. Wu, Y. L. Yang, S. Xiao, C. Wang, T. P. Russell and Y. Cao, Nat. Photonics, 2015, 9, 174-179.

7 X. Ouyang, R. Peng, L. Ai, X. Zhang and Z. Ge, Nat. Photonics, 2015, 9, 520-524.

8 L. Nian, W. Zhang, N. Zhu, L. Liu, Z. Xie, H. Wu, F. Wuerthner and Y. Ma, J. Am. Chem. Soc., 2015, 137, 6995-6998.
9 Y. J. Cheng, S. H. Yang and C. S. Hsu, Chem. Rev., 2009, 109, 5868-5923.

10 J. W. Chen and Y. Cao, Acc. Chem. Res., 2009, 42, 1709-1718. 11 G. D. Dennler, M. C. Scharber and C. J. Brabec, Adv. Mater., 2009, 21, 1323-1338.

12 G. Li, V. Shrotriya, J. S. Huang, Y. Yao, T. Moriarty, K. Emery and Y. Yang, Nat. Mater., 2005, 4, 864-868.

13 J. Peet, J. Y. Kim, N. E. Coates, W. L. Ma, D. Moses, A. J. Heeger and G. C. Bazan, Nat. Mater., 2007, 6, 497-500.

14 M. L. Keshtov, S. A. Kuklin, F. C. Chen, A. R. Khokhlov, R. Kurchania and G. D. Sharma, J. Polym. Sci., Part A: Polym. Chem., 2015, 53, 2390-2398.

15 T. L. Wang, S. C. Huang, C. H. Yang, Y. Y. Chuang and C. H. Chen, eXPRESS Polym. Lett., 2015, 9, 881-893.

16 Y. Huang, L. Huo, S. Zhang, X. Guo, C. C. Han, Y. Li and J. Hou, Chem. Commun., 2011, 47, 8904-8906.

17 S. C. Price, A. C. Stuart, L. Q. Yang, H. X. Zhou and W. You, J. Am. Chem. Soc., 2011, 133, 4625-4631.

18 H. J. Son, B. Carsten, I. H. Jung and L. P. Yu, Energy Environ. Sci., 2012, 5, 8158-8170.

19 H. Y. Chen, J. H. Hou, S. Q. Zhang, Y. Y. Liang, G. W. Yang, Y. Yang, L. P. Yu, Y. Wu and G. Li, Nat. Photonics, 2009, 3, 649-653.

20 Y. Y. Liang, Z. Xu, J. B. Xia, S. T. Tsai, Y. Wu, G. Li, C. Ray and L. P. Yu, Adv. Mater., 2010, 22, E135-E138.

21 D. Dang, W. Chen, R. Yang, W. Zhu, W. Mammod and E. Wang, Chem. Commun., 2013, 49, 9335-9337.

22 H. J. Son, W. Wang, T. Xu, Y. Liang, Y. Wu, G. Li and L. Yu, J. Am. Chem. Soc., 2011, 133, 1885-1894.

23 E. G. Wang, L. T. Hou, Z. Q. Wang, S. Hellstr, F. L. Zhang, O. Ingan and M. R. Andersson, Adv. Mater., 2010, 22, 52405244.

24 Y. H. Fu, H. Cha, S. Song, G. Y. Lee, C. E. Park and T. Park, J. Polym. Sci., Part A: Polym. Chem., 2013, 51, 372-382.

25 H. Wu, B. Qu, Z. Cong, H. Liu, D. Tian, B. Gao, Z. An, C. Gao, L. Xiao, Z. Chen, H. Liu, Q. Gong and W. Wei, React. Funct. Polym., 2012, 72, 897-903.

26 Z. Gao, B. Qu, H. Wu, H. Yang, C. Gao, L. Zhang, L. Xiao, Z. Chen, W. Wei and Q. Gong, Synth. Met., 2013, 172, 69-75.

27 H. Wu, B. Qu, D. Tian, Z. Cong, B. Gao, J. Liu, Z. An, C. Gao, L. Xiao, Z. Chen, Q. Gong and W. Wei, React. Funct. Polym., 2013, 73, 1432-1438.

28 Z. Cong, B. Zhao, H. Wu, Z. Guo, W. Wang, G. Luo, J. Xu, Y. Xia, C. Gao and Z. An, Polymer, 2015, 67, 55-62.

29 Y. Lu, Z. Xiao, Y. Yuan, H. Wu, Z. An, Y. Hou, C. Gao and J. Huang, J. Mater. Chem. C, 2013, 1, 630-637.

30 J. Yuan, L. Qiu, Z. Zhang, Y. Li, Y. Chen and Y. Zou, Nano Energy, 2016, 30, 312-320.

31 J. Yuan, L. Qiu, Z. Zhang, Y. Li, Y. He, L. Jiang and Y. Zou, Chem. Commun., 2016, 52, 6881-6884.

32 E. Wang, L. Hou, Z. Wang, Z. Ma, S. Hellstrom, W. Zhuang, F. Zhang, O. Inganas and M. R. Andersson, Macromolecules, 2011, 44, 2067-2073.

33 Y. Li, J. Ding, M. Day, Y. Tao, J. Lu and M. D'iorio, Chem. Mater., 2004, 16, 2165-2173. 
34 P. Dutta, W. Yang, S. H. Eom and S. H. Lee, Org. Electron., 2012, 13, 273-282.

35 R. L. Z. Hoye, M. R. Chua, K. P. Musselman, G. Li, M. L. Lai, Z. K. Tan, N. C. Greenham, J. L. MacManus-Driscoll, R. H. Friend and D. Credgington, Adv. Mater., 2015, 27, 1414-1419.
36 J. K. Lee, W. Ma, C. J. Brabec, J. Yuen, J. Moon, J. Y. Kim, K. Lee, G. C. Bazan and A. J. Heeger, J. Am. Chem. Soc., 2008, 130, 3619-3623.

37 J. Liu, L. Chen, B. Gao, X. Cao, Y. Han, Z. Xie and L. Wang, J. Mater. Chem. A, 2013, 1, 6216-6225. 